\title{
Decolonising the curriculum at a university of Technology in South Africa
}

\author{
Lawrence Meda ${ }^{1}$, Amanda Swart $^{2}$ and Nomakhaya Mashiyi ${ }^{3}$ \\ ${ }^{1}$ Lawrence Meda is a Senior Lecturer and Teaching and Learning Coordinator in the Faculty of Education at Cape Peninsula \\ University of Technology in South Africa. His research field is in Curriculum Studies \\ ${ }^{2}$ Amanda Swart is a Senior Lecturer at Cape Peninsula University of Technology in South Africa. her research interest is in \\ decolonisation of the curriculum \\ ${ }^{3}$ Nomakhaya Mashiyi is a Senior Lecturer at Cape Peninsula University of Technology and Faculty Language Coordinator. Her \\ research interest is in languages and decolonisation
}

How to cite this paper: Meda L, Swart A and
Mashiyi N. (2019). Decolonising the curriculum
at a university of Technology in South Africa.
The Educational Review, USA, 3(6), 50-57.
http://dx.doi.org/10.26855/er.2019.06.001

*Corresponding author: Lawrence Meda is a Senior Lecturer and Teaching and Learning Coordinator in the Faculty of Education at Cape Peninsula University of Technology in South Africa. His research field is in Curriculum Studies.

Email: medalawrence@gmail.com

\begin{abstract}
A good number of universities in South Africa came to a standstill in 2016 when student protests in quest for a decolonised curriculum intensified. Today, decolonisation has become a buzzword in the country's higher education institutions as academics are challenged to meditate around the term and integrate it into the curriculum. The purpose of this study is to investigate ways in which lecturers decolonise the curriculum. The study was done using a qualitative case study at a university of technology in South Africa. Rawls' theory of justice was used as a theoretical framework. Sixteen lecturers were selected to complete open-ended questionnaires. Data was analysed using content analysis. It was found that lecturers decolonise their curricula by integrating indigenous African knowledge and at the same time retaining Western knowledge in order to prepare students to be able to live and work in an international, intercultural and global environment.
\end{abstract}

\section{Keywords}

Decolonisation; Curriculum; University; Decentring; Indigenous Knowledge

\section{Introduction}

What started as a peaceful demonstration for free education (Fees Must Fall) in 2015 and 2016 escalated to an intense protest for decolonisation of the curriculum in South African universities. The \#FeesMustFall protests intensified and resulted in students demanding for a decolonised curriculum (South African Institute of Race Relations 2016, 7). Students protested that sculptures which depicted colonial icons such as the Cecil John Rhodes statue must be demolished wherever they are on a university campus (Murris 2016).

The \#RhodesMustFall movement which began at a University in Cape Town brought a renewed attention to the need to decolonise the curriculum in South African Higher Education (Prinsloo 2016). Calls to decolonise the curricula are not new in South Africa nor have they gone uncontested whenever they have been made (Mbembe 2016). Considering the contestable nature of decolonisation in higher education because of multiple perspectives about the phenomenon, there is a need to investigate how lecturers go about decolonising the curriculum. Thus, the purpose of this study is to investigate ways in which lecturers go about decolonising the curriculum. The study was guided by one research question: How do lecturers go about decolonising the curriculum?

The paper begins by defining the curriculum, followed by a decolonisation debate. This is followed by presentation of a theoretical framework, context of the study and methodology. Results and discussion follows along with succinct conclusions.

\subsection{The Curriculum and Decolonisation Debate}

There is no one universally accepted definition of the term curriculum. However, various scholars conceptualise it simply as a course of study or that which a learning institution wants students to learn (Marsh and Willis 1995; Pinar 2012; Pinar, Reynolds, Slattery, and Taubman 2008). The presence of many definitions of curriculum and the fact that it (curriculum) has 
many modalities resulted in Pinar (2012) concluding that curriculum is an extraordinarily complicated conversation.

According to Grumet $(1981 ; 2004)$ curriculum is autobiographical in the sense that it is thought and something that we live in the past, present and future. It is anything that students ought to experience by being part and parcel of a learning institution. Grumet's view of a curriculum as something that happened in the past, present and future is closely related to the decolonisation discussion. The view challenges lecturers in institutions of higher learning to rethink content which they would like students to learn about their past, present and future (Grumet 2004). Do academics want their students to completely disregard indigenous knowledge when they teach them about their past, present and future? Do they want students to learn predominantly Eurocentric and other Western theories without affording them opportunities to engage with indigenous knowledge systems? Such questions necessitate a heated and marathoned debate about decolonisation of the curriculum in South Africa.

The view that a curriculum is an extraordinarily complicated conversation (Pinar 2012) which can be conceptualised in multiple ways makes its decolonisation a bit challenging to approach. The thorny issue (of decolonising the curriculum) does not have a single approach (Le Grange 2016) and has furthermore been met with a lot of misinterpretations, dismissal and reprimand (de Oliveira Andreotti, Stein, Ahenakew, and Hunt 2015).

Academics have differing views about what decolonisation of the curriculum entails let alone implementing it. According to Chilisa (2012), decolonisation of the curriculum is associated with rediscovering and recovering ways of knowing and the knowledge which colonised people were denied by colonial masters. Le Grange (2016) concurs that decolonisation is about rediscovering and recovering ways of knowing that have been denigrated during the colonial and apartheid periods. It is about changing content knowledge to suit norms and values of citizens of a country. This is opposed to a curriculum that predominantly foreground needs and interests of colonial and apartheid powers.

Le Grange (2014) and Smith (1999) contend that decolonisation is about deconstructing and reconstructing knowledge in a way that enables a nation to select information or knowledge which it deems appropriate for its students to learn and apprize. It is about creating a curriculum that acknowledges and creates space for the voices and knowledge of indigenous people (Le Grange 2016). Decolonisation does not necessarily mean going back in time to a period when there was less modernity and no technology (Guattari 2001; Mgqwashu 2017). It does not mean kicking other racial groups away nor (Department of Education 2008) subjecting students to learn exclusively localised content (Heleta 2016). It is all about integrating indigenous knowledge into the curriculum so that students learn to treasure their norms, values and cultures (Meda 2017). It is about striking a balance so that indigenous knowledge finds its way into the curriculum rather than letting students in the $21^{\text {st }}$ century continue to study curriculum designed during and for colonial and apartheid periods (Prinsloo 2016).

Mbembe (2016: 32) openly attests that something is profoundly wrong in South African higher education institutions where 'syllabuses designed to meet the needs of colonialism and apartheid should continue well into the liberation era'. Heleta (2016b) echoes the same sentiments that twenty years after the demise of apartheid, South African societies in general and universities in particular are still entrenched in colonial and apartheid thinking as the curricula remain largely Eurocentric. The colonial and apartheid models of education and knowledge systems are still lingering in the post-apartheid South Africa since they have not been redressed in any serious way on the demise of apartheid (Le Grange 2016).

Similarly, Ramoupi (2014) postulates that the theoretical underpinnings of the content and curriculum of the South African higher education remains the same as it was during apartheid which ended in 1994. The curriculum has remained unchanged and unquestioned which has resulted in the exclusion and decimation of the knowledge of colonised people (Le Grange 2016b). Indigenous knowledge was viewed by colonial and apartheid administrators as unscientific, illogical and counter-productive (Mbembe 2016; Mawere 2015) to an extent of not acknowledging it, let alone integrating it into the curriculum. That is what contemporary scholarship seeks to decolonise by including indigenous African knowledge into the curriculum (Mawere and Mubaya 2016).

Le Grange (2016) postulates that there is a need for reviewing the curriculum in South Africa, not necessarily destroying Western knowledge, but decentring it. Decolonisation of the curriculum involves fundamental rethinking and reframing of the curriculum and bringing South Africa and Africa to the centre of teaching, learning and research (Heleta 2016). It is about valuing and integrating indigenous knowledge into the curriculum. Indigenous knowledge ought to have a place in the higher education curriculum so that students can begin to see things from their indigenous point of view. This resonates with Wa Thiongo's (1986) view that decolonising is about having a liberated perspective; a perspective that allows us 'to see ourselves clearly in relationship to ourselves and to other selves in the universe'. When students are afforded opportunities to learn about their indigenous knowledge, this will not only stimulate them to have a philosophy and sense of belonging (Mawere and Mubaya 2016), but also view the world with a liberated mind. It allows them to appreciate and extend their indigenous philosophical underpinnings.

Decolonisation of the current curriculum can be done in numerous ways. It can be done by simply incorporating knowledge of Africa by African scholars (Keet 2014). This includes taking into cognisance African philosophies, ideologies and cultural norms, values and principles. A good example is of incorporating the African philosophy of Ubuntu/botho into the curriculum. 
Ubuntu/botho is deeply rooted in many African cultures which include Zimbabwe, Malawi, South Africa, Botswana, Tanzania and Zambia. Instead of embedding a curriculum with purely Eurocentric content, why not integrate Afrocentric knowledge and philosophies as well (Mawere 2015; Pandey and Moorad 2003; Meda 2017).

The teaching of languages can be decolonised as was argued by Ngugi wa Thiong'o from a Kenyan perspective that there is a need to decolonise universities by teaching African languages (Wa Thiong'o 1986). Mbembe (2016, 36) concurs that "a decolonised university in Africa should put African languages at the centre of its teaching and learning project". The outcry for African languages to be in the centre of teaching stems from the argument that colonialism rhymes with monolingualism, whereas the African universities of today and tomorrow are characterised by multilingualism (Mbembe 2016; 2015). UNESCO $(2003,17)$ maintains that 'local languages are the means for preserving, transmitting, and applying traditional knowledge in schools. A bilingual or multilingual education allows the full participation of all learners; it gives learners the opportunity to confront, in the positive sense, the knowledge of their community with knowledge from elsewhere'.

\subsection{Theoretical Framework}

A theoretical framework guiding this study is Rawls' (1971) theory of justice which is centred on the socially just distribution of goods in a given society. The theory is underpinned by two fundamental principles: a principle of equal rights to all the people, and a principle of rearranging social and economic inequalities so that they can be to everyone's advantage (Rawls 1971). The two principles are relevant to this study as they represent racial groups which were previously disadvantaged by colonialism and apartheid. From the perspective of theory of justice, there is a need for ensuring that rights of previously denigrated people including their norms and values are embedded into the curriculum.

Fanon (1964) challenges academics to ensure that society is re-arranged in an equal and equitable manner where citizens' thinking do not have to be confined to Western ways of thinking. There is a need to break the bond of Western thinking by also incorporating indigenous African knowledge systems into the curriculum so that students can value and treasure their ways of knowing and thinking (Mawere 2015). Mbembe (2016) supports the notion of relooking at South African decolonisation using the social justice theory as there is a lot of under-representation and devaluing of indigenous knowledge in the current curriculum that students study. This explains why students in South African higher education broke into protests across the country wanting inequalities in education to be addressed through decolonisation.

\subsection{Context of the Study}

The study was done at a university of technology in South Africa. The university is one of the institutions which was temporarily closed in 2015 and 2016 due to student protests. It is one of the institutions which was severely affected by student protests where a lot of infrastructure was destroyed. The institution became a no go area for both students and staff in 2016 as protestors were intimidating and threatening people who were attempting to go to its campuses. As a result of the closure of the university in 2016, summative assessments were cancelled for first, second and third year students. Only final year students (fourth year) managed to write examinations at a highly secured off campus area as the campus was not safe since protesters vowed to continue protesting until their demand for a decolonised curriculum was met. The situation forced the university management to think about developing an institutional framework for decolonisation. Lecturers at the university were encouraged by institutional management to find ways to decolonise the curriculum in their respective subjects. This study (about how lecturers go about decolonising the curriculum) is a follow up of the first which focused on students and staff members' understanding of decolonisation at a university of technology.

\section{Methodology}

A paradigmatic position for this study is interpretive. An intepretivist paradigm was chosen as it allows the researchers to understand, interpret and describe ways in which lecturers are decolonising the curriculum. Schultz and Hatch (1996) postulate that an intepretivist paradigm seeks to interpret, understand and describe meaningful social actions and it creates opportunities for the researcher to understand meanings of a phenomenon. Intepretivist paradigm was also chosen as it seeks to answer why and how things are done. Lincoln (2010) argues that every interpretive paradigm seeks to answer why and to explain how things happen.

The study was done using a qualitative approach. A qualitative approach was chosen as it is compatible with an interpretive paradigm and they both allow participants to provide rich textual data about a phenomenon (Creswell 2012). Lapan, Quartaroli, and Riemer (2012) argued that all qualitative research has an interpretive perspective which focuses on uncovering participants' views. A case study design was selected as the study focused exclusively on a specific case of a Faculty of Education at a University of Technology where some of the lecturers have embarked on decolonising the curriculum of their respective modules. According to Cohen, Manion and Morrison (2007), case studies are very specific. They identify one group of participants, one setting and one situation or one event (Creswell 2008). A university of technology in question was selected because it is one of the institutions which was worst affected by student protests for a decolonised curriculum. It was also chosen because lecturers have begun to decolonise the curriculum in their modules. 
Sixteen lecturers volunteered to participate in the study by completing an open ended questionnaire. The questionnaire was originally sent to all 100 lecturers in the faculty, but only sixteen responded. An open ended questionnaire was preferred as it enabled participants to fully describe how they are decolonising the curriculum in their modules. Data were analysed using inductive content analysis. Ethical issues were observed by obtaining ethical clearance from the university, explaining the purpose of the study to all participants and constantly reminding them that participation was voluntary and they had freedom to withdraw from the study at any point in time.

\section{Findings}

Since inductive content analysis was used to analyse data, codes were developed and they were later collapsed into three main themes where findings were categorised into. The three main themes which emerged are: i) decolonisation as a topic for discussion in class; ii) Integration of Indigenous Knowledge Systems, and iii) Renewing modules. Each of these themes is presented in detail below.

\subsection{Theme 1. Decolonisation as a topic for discussion in class}

The study found that lecturers at a university of technology in question are decolonising the curriculum by teaching the subject (decolonisation) as a topic where students in lectures discuss in detail. One lecturer said,

I am teaching decolonisation in all my subjects and I discuss the topic with a lot of people. At this stage I have made a bibliography on the topic - colonisation and decolonisation and I am busy reading a lot about it.

Another lecturer said, "I embedded decolonisation as a discussion topic in my 2nd, 3rd and 4th year classes." The reason for embedding decolonisation as a topic is to afford students an opportunity to discuss the subject at length. Lecturers reiterated that one has to be very cautious when discussing decolonisation as it is a sensitive subject. A lecturer said,

Decolonisation to me is a new process which starts with discussions with colleagues, students and community. It needs to be approached in an empathetic and sensitive manner so as to ensure all parties buy into this concept. This is still in a planning phase and will only be implemented at a later stage. But for now, we are revisiting choices of prescribed literary works, and doing research in the field.

Some lecturers claimed to decolonise the curriculum in their modules indirectly by ensuring fairness and allowing all students equal opportunities to express themselves in class. A participant said,

I strive to make my lectures a space where students are able to express themselves on any topic where we can all learn from each other regardless of backgrounds. I make sure that content taught is relevant to the context in which we find ourselves and make sure that students understand the importance of social justice with regards to issues of poverty and other social barriers to learning. Students go out to schools weekly and engage with learners for learning support.

South Africa has a history of apartheid and colonial past where people were separated according to racial groups. Decolonisation in this case happens indirectly through bringing all races together and letting students engage into discussions and learn from one another.

\subsection{Theme 2. Integration of Indigenous Knowledge Systems}

The study found that lecturers are decolonising the curriculum by integrating indigenous African knowledge in their teaching. Lecturers are not necessarily discarding Western knowledge, but embedding indigenous African knowledge into the curriculum and also teach students about both Western and African theories. A lecturer said,

I am decolonising the curriculum in my module by teaching students about African knowledge systems as well as Western theories and to show how some African philosophies and theories can be used to explain information with Eurocentric origins. For example, teaching Social model of inclusive education and Ubuntu in Africa. I ask students to analyse papers written by African writers including myself (lecturer who is an African author). Students analyse and critique and evaluate the knowledge against what happens in their contexts as well as in Western settings.

Another lecturer who is decolonising the curriculum by integrating indigenous knowledge and acknowledging local authors said,

In my lectures, I still include examples of international artists, but I balance these by showing the same elements in the work of local artists. I wrote the national visual Art curriculum for grades 1 to 9, and in this document, there are many examples of local arts and crafts. Some practical projects draw inspiration from African artists and crafters, for example, Willie Bester, Muafangejo and Gerard Sekoto. In my classes, we look at South African resistance art, African body adornment and African masks and their significance. All that is done as a way to decolonise the curriculum.

Generally, lecturers are not decolonising the curriculum by discarding Western knowledge which is predominant in students' curricula today. They are advocating for a curriculum where South African content and other indigenous content are embedded. A lecturer clarified this issue by explaining his understanding of decolonisation: 
Decolonisation of the curriculum does not mean teaching students about South African content only. It does not mean shutting down all doors of information with Western origins, no. It simply entails integrating South African and African knowledge into the current curriculum that we have. Our current curriculum is predominantly Western. Thus, our students are orientated to internationalisation. We are therefore arguing that in addition to Western content that we are teaching our students, we have to bring in African knowledge as well. Thus, internationalisation will be attained in the sense that students will be enriched by their indigenous African knowledge and also Western knowledge. It is pointless to prepare students to be marketable internationally when in actual fact they cannot work in their local or national contexts. We are advocating for an inside-outside approach. Meaning, students learn what is in their country, region, continent (inside) and then abroad (outside).

The participant advocates for the attainment of decolonisation standards through widening students' knowledge by incorporating Western knowledge into the curriculum. In this case, students are not confined to learning local content only, but international content which will prepare them to live and work in different contexts. The Western knowledge along with indigenous knowledge are essential in a $21^{\text {st }}$ century curriculum as they enable students to become active participants in a global economy.

Another participant echoed the same sentiments about decolonisation not being an exercise of discarding Western knowledge: "I do not believe that decolonisation means denuding the curriculum of international knowledge. I believe that it is an interweaving of indigenous, national and international knowledge in appropriate and meaningful ways." One lecturer explained how she is decolonising the curriculum in her module in a way that does not discard Western knowledge. She said:

In my module, I am teaching African theories, referring to African authors and most importantly show the relationship between Western theories and African ideologies of Ubuntu. I let students make podcasts of inclusive education in their communities and schools and compare that with Western and African theories.

Giving students opportunities to create their own podcasts and compare them with Western and African theories enable them to learn more about a particular phenomenon from multiple perspectives.

\subsection{Theme 3. Renewing modules}

Some lecturers are decolonising the curriculum by renewing their modules so that students can be afforded opportunities to learn about the phenomenon. A lecturer said "I am busy renewing my curriculum or modules in order to make space (into the curriculum) for students to study information about decolonisation." Another lecturer said "I am using a bottom up approach where students are actively involved in curriculum development because they are the people who advocated for a decolonised curriculum." Lecturers are mindful of the view that the curriculum they are reviewing should have some elements of social justice and diversity in nature. One lecturer said,

I work towards a social justice curriculum which explores the production of knowledge across the world. I designed a service learning course in which my students are grappling with how to conceptualise their lived experiences and those of others which inform their practice.

Lectures are decolonising the curriculum differently according to their respective modules / subjects. Lecturers who teach literature have embarked in the decolonisation process in a way that is relevant to their area. One literature lecturer said, "I am decolonising by giving more attention to multilingualism and a wider scope in prescribed literature to broaden the knowledge about cultures other than my own." Similarly, another literature lecturer is decolonising by "discussing the trends in literature and the meaning of language across cultures and inculcating a positive attitude towards multilingualism." Another lecturer has decolonised by using students' reading materials. The lecturer said, "Some of the newspaper and journal articles I use for teaching Academic Literacy focus on decolonisation and transformation in higher education."

In Mathematics, lecturers had mixed feelings about decolonisation. Some blatantly showed no interest of decolonising in their subject as was stated: "decolonisation does not apply very much in Maths. South African students are so much behind in Mathematics when compared with the rest of the world yet we still speak about decolonisation." Another lecturer simply indicated that he has not begun to decolonise the curriculum in Mathematics. A different lecturer responded saying, "what is missing from our curriculum is a separate course that runs across the programme - Maths and society in which students come to understand that Mathematics is not neutral......Mathematics is deeply political."

A lecturer who teaches inclusive education said "I have begun decolonising my module by introducing students to various African philosophies and I use both Western and Africa theoretical frameworks to guide my teaching and assessment." When students are exposed to various knowledge systems, they stand a greater chance of diversifying their knowledge and understanding in education.

\section{Discussion}

The three main themes that came out of this study (i. curriculum as a topic for discussion, ii. integrating indigenous African knowledge and iii. renewing modules) are reflective of a society which is striving to ensure social justice by valuing knowledge 
systems of previously denigrated racial groups. This concurs with this study's theoretical framework which is underpinned by the fundamentals of equality for all and a view that rearrangement of social injustice is inevitable in the contemporary society (Rawls 1971).

Based on different ways of decolonising the curriculum given by lecturers of different subjects, it is clear that there is no one strategy being applied. Decolonisation can be done in as many ways as there are lecturers teaching different subjects. Despite differences in terms of approaching decolonisation, lecturers unanimously decolonise by integrating indigenous knowledge into their curriculum in order to let students view issues from their local perspectives (Mawere 2015). This concurs with Wa Thiong'o (1986) who postulates that academics ought to decolonise the curriculum so that students can have opportunities to view things with a liberated perspective which allows them to see themselves clearly in relationship to others in the universe.

There is a need for the current curriculum to foreground indigenous knowledge which is now popularly known as the process of decentring (Prinsloo 2016). Decolonising the curriculum by decentring implies legitimising and foregrounding indigenous African knowledge into the present curriculum (Le Grange 2016b; Mawere 2015). Le Grange (2016) concurs that academics in higher education have to put indigenous knowledge at the centre so that students can begin to appreciate and understand things using their local perspectives rather than being influenced by Western knowledge to understand themselves. Wa Thiong'o (1986) extends this view by arguing that decolonisation is about rejecting the centrality of the west in Africa's understanding of itself and its place in the world. This is consistent with Rawls' (1971) two principles of social justice which supports equal rights and benefits to previously oppressed people.

Decolonisation does not in any way mean discarding Western knowledge and making students study local content only (Mgqwashu 2015; 2017). Universities today are striving to prepare students to be able to live and work in an international, intercultural and global environment (Meda and Monnapula-Mapesela 2016). Thus, a curriculum that comprises of exclusively local content will not be able to prepare students to become active participants in the current global economy. That is why Western content needs to be retained when integrating indigenous knowledge.

All subjects can be decolonised by bringing in an element of the local context during the teaching. Even languages can be decolonised in universities by teaching African languages (Wa Thiong'o 1986). Mbembe $(2016,36)$ states that "a decolonised university in Africa should put African languages at the centre of its teaching and learning project". The need for decolonising languages come from the view that colonialism rhymes with monolingualism when in actual fact African university of today is characterised by multilingualism (Mbembe 2016; 2015). UNESCO $(2003,17)$ states that "local languages are the means for preserving, transmitting, and applying traditional knowledge in schools. A bilingual or multilingual education allows the full participation of all learners; it gives learners the opportunity to confront, in the positive sense, the knowledge of their community with knowledge from elsewhere."

\section{Conclusion}

The purpose of this study was to investigate ways in which lecturers decolonise the curriculum in their respective modules. The study was guided by one research question: How do lecturers decolonise the curriculum in their modules? Lecturers are decolonising the curriculum by deliberately integrating indigenous African knowledge into the current Westernised curriculum which students are studying. The decolonisation process is being done in a systematic way that does not result in discarding Western knowledge. Academics are mindful of the fact that as much as they would like to decolonise the curriculum, they also have to teach student international content so that they will be able to live and work in a global economy. Thus, lecturers are integrating by foregrounding indigenous knowledge into the Western curriculum so that students simultaneously learn local theories, philosophies and paradigms and at the same time stay abreast with international, intercultural and global dimensions. Lecturers are also integrating by revising content of their modules and give students opportunities to converse in class about decolonisation.

\section{Recommendations}

Some lecturers, for example in Mathematics have not embarked on the decolonisation process like others. This could be a result of being sceptical about what decolonisation entails let alone exercising it in their subjects. In light of this unexpected finding, the study recommends capacity development workshops to be conducted with lecturers so that academics may discuss what decolonisation entails and how it can be done in different subjects. Alternatively, universities can have colloquiums or any academic gathering where lecturers can share best practices about decolonisation. That will help a lot in terms of capacitating lecturers who may not be aware of strategies to decolonise their subjects. If workshops to capacitate lecturers are not conducted, it may result in some lecturers teaching exclusively local information and completely disregarding Western knowledge. That could result in tertiary institutions producing graduate who are unable to participate in a global economy in the current $21^{\text {st }}$ century. 


\section{References}

Chilisa, B. (2012). Indigenous Research Methodologies. Los Angeles: Sage Publications.

Cohen, L., L. Manion, and K. Morrisson. (2007). Research Methods in Education. New York: Routledge.

Creswell, W. J. (2008). Educational Research. Planning, Conducting and Evaluating Quantitative and Qualitative Research. New Jersey: Merrill Prentice Hall.

Creswell, J. W. (2012). Educational research: Planning, conducting and evaluating quantitative and qualitative research. Boston, Pearson.

de Oliveira Andreotti, V., Stein, S., Ahenakew, C., and Hunt, D. (2015). "Mapping interpretations of decolonization in the context of higher education." Decolonization: Indigeneity, Education \& Society. 4(1). pp 1-5.

Department of Education (2008). Report of the Ministerial Committee on Transformation and Social Cohesion and the Elimination of Discrimination in Public Higher Education Institutions. Final Report. Pretoria: Department of Education.

Fanon, F. (1964). Toward the African revolution. New York: Grove Press.

Grumet, M. R. (1981). "Restitution and reconstruction of educational experience: An autobiographical method for curriculum theory." In M. Lawn, and L. Barton (Eds.). Rethinking curriculum studies: A radical approach, (pp. 115-130). London: Croom Helm.

Grumet, M. R. (2004). “Autobiography and Reconceptualization.” In W. F. Pinar (Ed). Contemporary Curriculum Discourses: Twenty years of JCT, (pp. 24-30). New York: Peter Lang Publishing.

Guattari, F. (2001). The three ecologies. London: The Athlone Press.

Keet, A. (2014). "Epistemic'othering' and the decolonisation of knowledge." Africa Insight, 44(1). pp. 23-37.

Lapan, D. S., Quartaroli, T. M. and Riemer. J. F. (2012). "Introduction to qualitative research.” In S.D Lapan, T. M Quartaroli and J. Riemer (Eds.). Qualitative Research. An Introduction to Methods and Designs, (pp. 3-18). San Francisco: Josey-Bass.

Le Grange, L. (2014). "Currere's active force and the Africanisation of the university curriculum." South African Journal of Higher Education 28(4). pp. 1284-1294.

Le Grange, L. (2016). "Decolonising the University Curriculum.” South African Journal of Higher Education 30(2). pp. 1-12.

Heleta, S. (2016). "Decolonisation of higher education: Dismantling epistemic violence and Eurocentrism in South Africa." Transformation in Higher Education 1 (1): 1-8.

Heleta, S. (2016b). Decolonisation: academics must change what they teach, and how. Accessed 12 August 2017. https:// theconversation.com/decolonisation-academics-must-change-what-they-teach-and-how-68080

Le Grange, L. (2016b). "Decolonisation involves more than simply turning back the clock." The conversation. Accessed 12 June 2017. http://theconversation.com/decolonisation-involves-more-than-simply-turning-back-the-clock-62133

Marsh, C., and Willis, G. (1995). Curriculum: Alternative Approaches, Ongoing Issues. New Jersey: Prentice Hall.

Mawere, M. (2015). "Indigenous Knowledge and Public Education in Sub-Saharan Africa." Africa Spectrum 50(2). pp 57-71.

Mawere, M., and Mubaya, T. R. (2016). African philosophy and thought systems. A search for a culture and philosophy of belonging. Bamenda: Langaa Research and Publishing.

Mbembe, A. (2015). Decolonizing knowledge and the question of the archive. Accessed 09 July 2017. http://wiser.wits.ac.za/ system/files/Achille\%20Mbembe $\% 20-\% 20$ Decolonizing\%20Knowledge $\% 20$ and $\% 20$ the $\% 20$ Question $\% 20$ of $\% 20$ the $\% 20$ Archive.pdf

Mbembe, A. J. (2016). "Decolonizing the university: New directions." Arts \& Humanities in Higher Education 15(1). pp. $29-45$.

Meda, L. (2017). "Decolonising the curriculum in the digital era: a student perspective." Paper presented at an International Conference on Communication and Information Science in a Science, Technology, Engineering and Mathematics (STEM) Environment, 21-24 August 2017, Caribbea Bay Hotel, Kariba, Zimbabwe.

Meda, L. and Monnapula-Mapesela, M. (2016). "Going Wide, Not Wild: Varying Conceptualizations of Internationalization at a University of Technology in South Africa." Journal of Studies in International Education 20(3). pp. 282-294.

Mgqwashu, M. (2015). "Decolonisation should be about appreciating difference, not despising it." The Conversation. Accessed 27 March 2018 http://theconversation.com/decolonisation-should-be-about-appreciating-difference-not-despising-it-51370

Mgqwashu, M. (2017). "The role of ICT in the decolonisation of South African University Curricula: Technology is Key." Cape Digital Foundation. Accessed 14 March 2017 http://www.digitalfoundation.org.za/2017/03/role-of-ict-in-decolonisationsouth-african-university-curricula/

Murris, K. (2016). “\#Rhodes must fall: A posthumanist orientation to decolonising higher education institutions." South African Journal of Higher Education 30(3). pp. 274-294. 
Pandey, S.N. and Moorad, F. R. (2003). “The Decolonization of Curriculum in Botswana.” In W. F Pinar (Ed.). International handbook of curriculum research, (pp. 143-170). New Jersey: Lawrence Erlbaum Associates.

Pinar, W. F. (2012). What is Curriculum Theory? Routledge, New York.

Pinar, W. F., Reynolds, W. M., Slattery, P., and Tauban, P. M. (2008). Understanding Curriculum. New York: Peter Lang Publishing.

Prinsloo, E. H. (2016). "The role of the Humanities in decolonising the academy." Arts \& Humanities in Higher Education 15(1). pp. 164-168.

Rawls, J. (1971). A Theory of Justice. Cambridge: Harvard University Press.

Ramoupi, N. L. L. (2014). "African research and scholarship: 20 years of lost opportunities to transform higher education in South Africa." Ufahamu: A Journal of African Studies 38(1). 269-286.

Smith, L. (1999). Decolonising Methodologies: Research and indigenous peoples. London: Zed Books.

South African Institute of Race Relations. (2016). Fees can fall, but first... South African Institute of Race Relations, Johannesburg.

United Nations Educational, Scientific and Cultural Organisation (UNESCO). 2003. Education in a Multicultural World, UNESCO Educational Paper. Fontenoy, Paris.

Wa Thiong'o, N. (1986). Decolonising the Mind: The Politics of Language in African Literature. Portsmouth: Heinemann. 